\title{
Graphene nanoplatelets and reduced graphene oxide elevate the microalgal cytotoxicity of nano-zirconium oxide
}

\author{
Zhuang Wang a, *, Fan Zhang ${ }^{\text {b }}$, Martina G. Vijver ${ }^{\text {b }}$, Willie J.G.M. Peijnenburg b, c \\ a School of Environmental Science and Engineering, Collaborative Innovation Center of Atmospheric Environment and Equipment Technology, Jiangsu Key \\ Laboratory of Atmospheric Environment Monitoring and Pollution Control, Nanjing University of Information Science and Technology, Nanjing, 210044, PR \\ China \\ ${ }^{\mathrm{b}}$ Institute of Environmental Sciences (CML), Leiden University, PO Box 9518, 2300 RA, Leiden, the Netherlands \\ ${ }^{\mathrm{c}}$ National Institute of Public Health and the Environment (RIVM), Center for the Safety of Substances and Products, PO Box 1, 3720 BA, Bilthoven, the \\ Netherlands
}

\section{H I G H L I G H T S}

- This is the first study to explore synergistic effects of mixtures of carbon-based NMs associated with metal NPs.

- Exposure to GNPs and/or RGO induced enhanced cytotoxicity of $\mathrm{nZrO}_{2}$ to algae.

- Cellular oxidative stress and membrane functional changes led to toxicity increase.

- Mitochondria-generated ROS regulated treatment-induced cellular response.

- RGO induced more cytotoxic responses from algal cells than GNPs.

\section{A R T I C L E I N F O}

\section{Article history:}

Received 20 November 2020

Received in revised form

2 February 2021

Accepted 17 February 2021

Available online 20 February 2021

Handling Editor: James Lazorchak

\section{Keywords:}

Graphene

Zirconium oxide

Aquatic nanotoxicity

Mixture toxicity

Toxic mechanisms

\section{G R A P H I C A L A B S T R A C T}

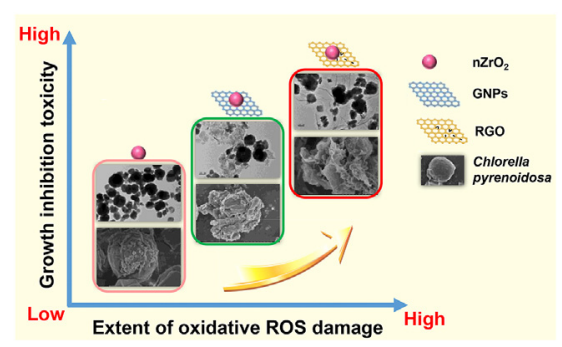

\footnotetext{
* Corresponding author.

E-mail address: zhuang.wang@nuist.edu.cn (Z. Wang).
} 
risk assessment of mixtures of graphene-based carbon nanomaterials and other ENPs, and fit the new ideas on product testing that respects the combination effects.

๑) 2021 Elsevier Ltd. All rights reserved.

\section{Introduction}

Nanotechnology has been thoroughly incorporated into modern society, with industries producing increasing amounts of nanomaterials (NMs) for various purposes, including biomedical applications, electronics/telecommunications, agriculture, and renewable energy (Ma et al., 2015; Sohn et al., 2015; Sun et al., 2020). At present, graphene-based carbon materials (GCMs) are becoming popular because they have fascinating nanostructures and have exceptional properties (Peng et al., 2020). Environmental health and human safety of GCMs are critical requirements for their wide range of applications (Chen et al., 2020; Fadeel et al., 2018), and numerous studies have been conducted to probe the ecotoxicity of GCMs in the past few years (Castro et al., 2018; Freixa et al., 2018; Hu et al., 2015a; Nogueira et al., 2015; Pretti et al., 2014). It has been reported that GCMs can provoke toxic effects on numerous ecological species, e.g. green algae (Du et al., 2016; Hu et al., 2015b; Zhao et al., 2017), water fleas (Cano et al., 2017; Feng et al., 2015; Lv et al., 2018), and fish (Bangeppagari et al., 2019; Manjunatha et al., 2018; Zheng et al., 2019). Hence, GCMs represent a new and emerging class of pollutants for which relatively little is known about their effects in the environment.

Current studies on the eco-toxicity of GCMs are based predominantly on assessments carried out on individual materials (Chen et al., 2020; Marchi et al., 2018; Wang et al., 2019). Since products typically embed a multitude of NMs rather than being composed of one single NM, organisms, as well as the environment in which they reside, are exposed to a wide variety of substances. Koivisto et al. (2017) developed a library that contains the release data from nano-enabled products. The studies included in the library led to the conclusion that there is a lack of understanding of joint stress of multiple NMs. Koivisto et al. (2017) proposed to mimic the stress scenario by following standardized test procedures or by simulating the spray process in environmentally relevant and well-controlled conditions. The sampling of released fragments should be harmonized so that it can be linked to hazard assessment and further risk assessment. Once fragments from NM-products are released, their fate and possible subsequent NM release and transformation depend on the composition of the surrounding medium. In this regard, it is important to note that most toxicological studies are conducted on pristine NMs (Srivastava et al., 2015). Several studies have reported that NMs may interact differently with and within biological and ecological systems, which implies that deviations from additivity of the joint effects can occur. For instance, nano- $\mathrm{TiO}_{2}$ was shown to reduce the impacts of nano-ZnO on the hatching of zebrafish embryos (Hua et al., 2016). What is more, the coexistence of nano- $\mathrm{ZnO}$ and nano- $\mathrm{CeO}_{2}$ induced synergistic cytotoxicity to Nitrosomonas europaea cells (Yu et al., 2016). Moreover, nano- $\mathrm{SiO}_{2}$ and nano- $\mathrm{TiO}_{2}$ synergistically triggered macrophage inflammatory responses (Tsugita et al., 2017). Limited studies on multiple NMs consisting of GCMs and other NMs indicated that the effects of NM mixtures are in general less than the summed effects of the individual NMs. For example, graphene oxide (GO) and nano-ZnO were antagonistic to Danio rerio, and GO contributed less than nano-ZnO to the joint toxicity (Ye et al., 2018). Likewise, the presence of GO reduced the bioavailability and toxicity of nano-ZnO in human A549 cells (Wu et al., 2019). Overall, these reports indicate that the toxic potential of multiple NMs can have impacts that deviate from additivity impacts; that is being the summed toxicity of individual NMs.

Nano-zirconium oxide $\left(\mathrm{nZrO}_{2}\right)$ is an emerging material with potentially extensive applications in amongst all ceramics, artificial jewelry, fire-retarding materials, optical storage, light shutters, stereo television glasses (Liu et al., 2016; Zhao et al., 2008). To date, most attention is focused on the interaction of $\mathrm{nZrO}_{2}$ with GCMs, which provides an exciting new array of ideas and applications (Cho and Ko, 2013; Jafari et al., 2018; Sun et al., 2013; Zhou et al., 2016). Especially expanded (or exfoliated) graphite nano-platelets $(\mathrm{xGnP})$ significantly outperform most other forms of carbon in terms of thermal conductivity, electrical conductivity, and mechanical properties. What is more, $\mathrm{xGnP}$ significantly improves the impermeability of composites because of the platelet shape. Furthermore, sewage systems and municipal wastewater treatment plants have become important intermediate pathways for metalbased nanoparticles (NPs) and carbon-based NMs transfer into the environment since industrial and municipal wastewater are considered to be the main source of metal-based NPs (Brar et al., 2010; Sousa and Ribau Teixeira, 2020) and carbon-based NMs (Suárez-Iglesias et al., 2017; Yin et al., 2020). It is reasonable to assume that the continuing development and use of nanocomposites will lead to $\mathrm{nZO}_{2}$ with GCMs jointly being accidentally discharged into the environment, in turn posing unknown combined risks to organisms.

In the work presented herein, we investigated the microalgal cytotoxicity of binary mixtures consisting of $\mathrm{nZrO}_{2}$ and two representative GCMs, namely graphene nanoplatelets (GNPs) and reduced graphene oxide (RGO). To compare with the toxic effects induced by the mixture components, the aquatic toxicity of individual GNPs and RGO, as well as the zirconium ion $\left(\mathrm{Zr}^{4+}\right)$ as a counterpart of zirconium element was also observed. We used Chlorella pyrenoidosa as a model organism being a representative freshwater green algae, which has an important ecological role in the aquatic food chain and a primary agent for global biogeochemical cycles (Chen et al., 2012). We first determined the effect concentrations of $\mathrm{nZO}_{2}$ and $\mathrm{Zr}^{4+}$ in the absence and presence of GNPs and RGO, subsequently elucidated the mechanisms of toxicity of intracellular oxidative stress and cellular membrane function disruption. Additionally, the superficial- and ultra-structures of C. pyrenoidosa exposed to the studied toxicants were analyzed. Taken together, our findings help to clarify the mechanisms underlying the total impact on algae in the co-occurrence of different NPs.

\section{Materials and methods}

\subsection{Test materials and medium}

GNPs were purchased as powders with a thickness of 1-4 nm and particle size of $2 \mu \mathrm{m}$ from PlasmaChem GmbH (Berlin, Germany). RGO was purchased as powders with thicknesses of $0.8-1.2 \mathrm{~nm}$ and diameters of $0.5-5 \mu \mathrm{m}$ from Nanjing XFNANO Materials Tech Co., Ltd (Nanjing, China). $\mathrm{nZrO}_{2}$ with a primary size of 5-25 nm (advertised specific surface area $130 \pm 20 \mathrm{~m}^{2} / \mathrm{g}$; purity $>97.2 \%$ ) was purchased from PlasmaChem GmbH (Berlin, 
Germany). A reagent grade Zirconium (IV) chloride $\mathrm{ZrCl}_{4}, \mathrm{CAS}$ No. 10026-11-6) with a purity of $99.9 \%$ on a metal basis was purchased from Aladdin Industrial Corporation (Shanghai, China) and also tested to determine the sensitivity of the test organism to ionic zirconium $\left(\mathrm{Zr}^{4+}\right)$. Stock suspensions of the test materials were prepared by dispersing powders in ultrapure water, and thereafter the stock suspensions were sonicated for $30 \mathrm{~min}$ in a temperaturecontrolled sonication bath. A test suspension was prepared by adding, dropwise, an aliquot of the stock GNPs/RGO suspensions to the algae culture medium (ACM) whilst stirring with a magnetic stirring apparatus. The ACM was prepared at $\mathrm{pH} 7.8 \pm 0.2$ according to OECD guideline 201 (OECD, 2006).

\subsection{Physicochemical analyses}

A transmission electron microscope (TEM, FEI-Tecnai G2F20, Hillsboro, OR, USA) was used to characterize the morphology of the studied materials in the ACM. The surface chemistry of GNPs and RGO was characterized by X-ray Photoelectron Spectroscopy (XPS, Thermo Scientific ESCALAB 250Xi, USA). The zeta potential and the hydrodynamic diameter of the individual and binary materials were analyzed by a ZetaSizer (Nano ZS90, Malvern Instruments Ltd., Worcestershire, UK) at $0,24,48$, and $72 \mathrm{~h}$ after incubation in the ACM. The physicochemical property measurements were carried out at the concentration of $1 \mathrm{mg} / \mathrm{L}$ of GNPs/RGO and effect concentrations of $\mathrm{nZrO}_{2}$, namely $10 \%$ effect concentration $\left(E C_{10}\right)$ and $50 \%$ effect concentration $\left(E C_{50}\right) . \mathrm{nZrO}_{2}$ is an inert nanoparticle similar to nano- $\mathrm{TiO}_{2}$. Although the potential ion release from the particles was followed over time, the dissolved ion concentration was below the detection limit of inductively coupled plasma mass spectrometry (Thermo Fisher iCAP-Q, Germany).

\subsection{Growth inhibition bioassay}

The OECD Guideline 201 with slight modifications was used to test the algal growth-inhibition toxicity of the studied materials to C. pyrenoidosa (OECD, 2006). The growth inhibition test of C. pyrenoidosa was conducted for $72 \mathrm{~h}$ with three replicates for each treatment. The algal cells at the logarithmic stage of growth were re-suspended in a freshly prepared OECD medium to obtain a cellular density of $4 \times 10^{5}$ cells/mL used for the testing. The algae used for toxicity testing were maintained at $24 \pm 1.0{ }^{\circ} \mathrm{C}$ with a photoperiod of $12 \mathrm{~h}$ of light (3000-4000 L) and $12 \mathrm{~h}$ of dark in a climatic chamber, and were shaken manually three times a day. Algae were exposed to increasing initial concentrations of $\mathrm{nZrO}_{2}$ (from 1 to $50 \mathrm{mg} / \mathrm{L}$ ) and $\mathrm{Zr}^{+4}$-ions (from 0.1 to $25 \mathrm{mg} / \mathrm{L}$ ) in the absence and presence of GNPs and RGO (0.1 and $1 \mathrm{mg} / \mathrm{L}$ ). Concentration-response curves (CRCs) were fitted based on different response measures. For each batch of toxicity tests, the treatments of individual GNPs and RGO of 0.1 and $1 \mathrm{mg} / \mathrm{L}$ were also included. The algal cell density in each flask was determined after $72 \mathrm{~h}$ to allow the specific growth rate to be calculated. Growth inhibition (\%) was calculated by dividing the specific growth rate for a treatment by the mean specific growth rate of the runs $(n=3)$ for the controls.

\subsection{Biomarker assays}

To detect the formation of reactive oxygen species (ROS) in algae cells, a fluorescent probe with $2^{\prime}, 7^{\prime}$-dichlorodihydrofluorescein diacetate (DCFH-DA) reagent purchased from Macklin Biochemical Co., Ltd (Shanghai, China) was used. When intracellular ROS was generated, DCFH-DA was broken down into DCFH by the lipase enzyme, after which DCFH was converted into $2^{\prime}, 7^{\prime}$ - dichlorodihydrofluorescein (DCF). The degree of ROS generation can be quantified by the fluorescence intensity (FI) of DCF. To gather the algae cells, 72-h algal cell suspensions were centrifuged at $15,000 \mathrm{rpm}$ for $15 \mathrm{~min}$ at $4{ }^{\circ} \mathrm{C}$ using a D3024 high-speed microcentrifuge (Scilogex, Rocky Hill, CT, USA). Subsequently, cells were incubated with $10 \mu \mathrm{M}$ DCFH-DA for $30 \mathrm{~min}$ at $25^{\circ} \mathrm{C}$ in the dark and then washed three times with the algae culture medium. FI of DCF was measured by a fluorescence spectrophotometer (F96PRO, Shanghai Kingdak Scientific Instrument Co., Ltd., Zhejiang, China). The relative ROS level was calculated as a percentage (\%) of the treatment compared to the control. ROS tracking was analyzed using a fluorescent microscope OLYMPUS BX51 (Olympus Corp., Tokyo, Japan).

Fluorescein diacetate (FDA, Aladdin), a fluorescent chemical, was used to measure cellular membrane permeability (CMP). Nonionic and non-fluorescent FDA can enter the cells via passive uptake by the algae. FDA is then hydrolyzed in the cells, producing the fluorescent molecule fluorescein. Before incubating with $10 \mu \mathrm{M}$ FDA at $25{ }^{\circ} \mathrm{C}$ for $30 \mathrm{~min}$ in the dark, 72-h algal cells need to be obtained by centrifugation $\left(15,000 \mathrm{rpm}, 15 \mathrm{~min}, 4^{\circ} \mathrm{C}\right.$, using the D3024 high-speed micro-centrifuge). After that, the cells were washed three times with the algae culture medium under the same conditions. FI was measured using the fluorescence spectrophotometer. The CMP data were expressed as a percentage (\%) of the fluorescence of the control cells.

Rhodamine 123 ( $R$ h 123) purchased from the Aladdin Industrial Co. was used as a cationic fluorescent probe to measure mitochondrial membrane potential (MMP). Once the cells are equilibrated with the probe, depolarization (decrease in potential difference) will cause the release of the dye into the medium, and hyperpolarization (increase in potential difference) will cause uptake of the dye. 72-h algal cells obtained by centrifugation $\left(15,000 \mathrm{rpm}\right.$ at $4{ }^{\circ} \mathrm{C}$ for $15 \mathrm{~min}$, using the D3024 high-speed microcentrifuge) were subjected to $30 \mathrm{~min}$ of incubation using $10 \mu \mathrm{M} \mathrm{Rh}$ 123 at $25{ }^{\circ} \mathrm{C}$ under dark conditions, followed by washing three times with the algae culture medium. FI was measured using the fluorescence spectrophotometer. The MMP data were expressed as a percentage (\%) of the fluorescence of the control cells. The excitation and emission wavelength for the fluorescence measurements of ROS, CMP, and MMP were based on previous studies (Hu et al., 2015b; Meng et al., 2018).

\subsection{Analysis of cellular superficial- and ultra-structures}

Superficial- and ultra-structures of $C$. pyrenoidosa exposed to $\mathrm{nZrO}_{2}$ in the absence and presence of GNPs and RGO were characterized using a Hitachi S-4800 cold-cathode field-emission scanning electron microscope (SEM, Hitachi, Tokyo, Japan) and a TEM (JEM-1011, JEOL Ltd., Japan). Briefly, 72-h algal suspensions were centrifuged at $4000 \mathrm{rpm}$ for $1 \mathrm{~h}$ at $25^{\circ} \mathrm{C}$. Algal cells were then chemically fixed for $2 \mathrm{~h}$ using $2.5 \%$ glutaraldehyde. A series of preprocessing processes were carried out as described previously reported methods (Liu et al., 2018; Meng et al., 2018).

\subsection{Statistical analysis}

All values were reported as means \pm standard deviation (SD). Statistically significant differences between groups were determined by one-way analysis of variance at significance levels of $p<0.05, p<0.01$, and $p<0.001$. CRCs were described using a sigmoidal relationship by performing regression models using the Logistic model in Sigma Plot, Ver. 10.0 (Systat Software Inc., San Jose, CA). 

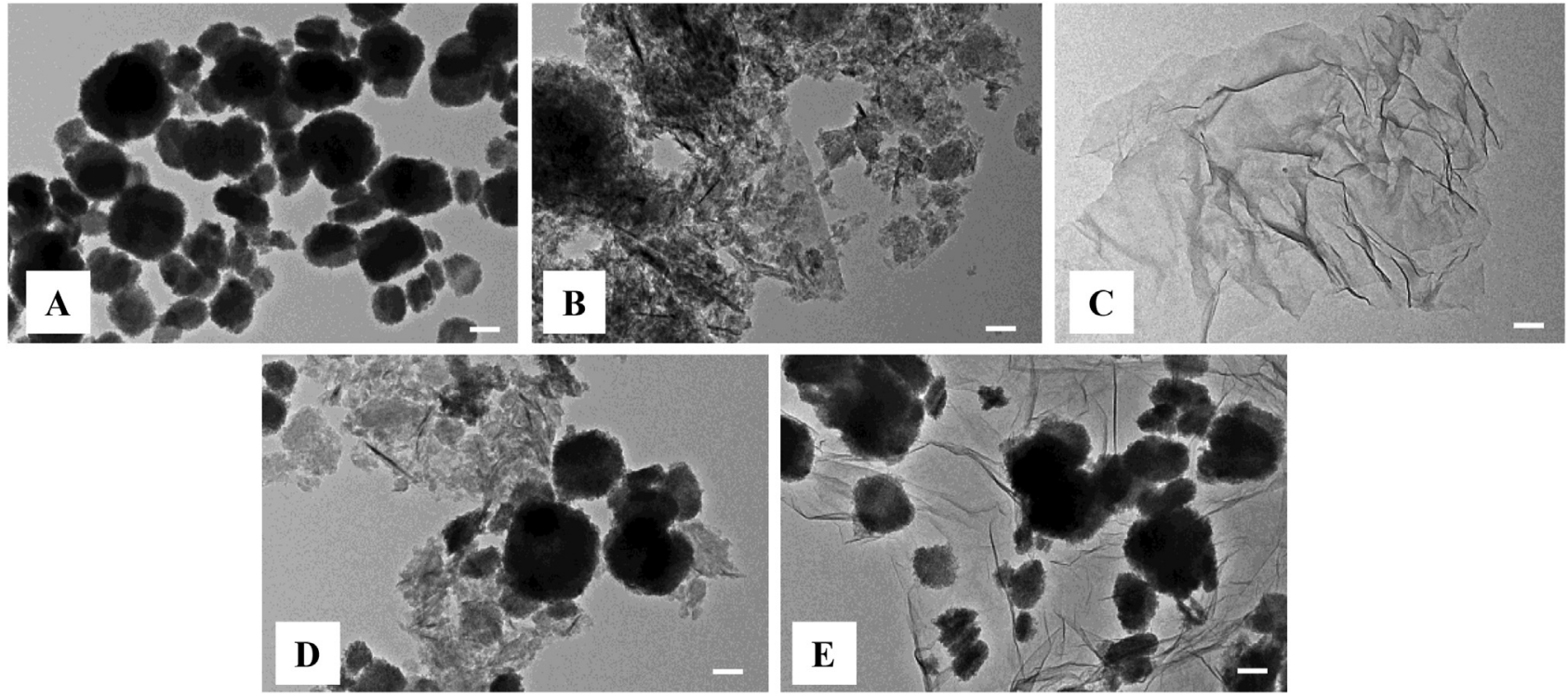

Fig. 1. TEM images of $\mathrm{nZrO}_{2}(\mathrm{~A})$, GNPs (B), and $\mathrm{RGO}(\mathrm{C})$, as well as $\mathrm{nZrO}_{2}$ in the presence of GNPs (D) and RGO (E) in the test medium. The white bar is 100 nm.

\section{Results and discussion}

Concern has been raised that exposure of organisms to systems containing multiple metal-oxide-based NPs might induce effects that significantly exceed the summed effects of the individual constituents of the mixture (Tsugita et al., 2017; Yu et al., 2016). As far as we are aware, this is the first study that explores the synergistic cytotoxicity induced by different carbon NMs and metalbased NPs.

\subsection{Morphology analysis of studied materials}

Fig. 1 shows the transmission electron microscope (TEM) images of the individual GNPs, RGO and $\mathrm{nZrO}_{2}$, as well as $\mathrm{nZrO}_{2}$ in the presence of GNPs and RGO. It can be observed that the $\mathrm{nZrO}_{2}$ was spherical-like and agglomerated intensely (Fig. 1A). The TEM image marked in Fig. 1B revealed that GNPs with a sheet structure intensely agglomerated. RGO was slightly transparent and consisted of expanded and corrugated nanosheets, as shown in Fig. 1C. Moreover, it is observed that $\mathrm{nZrO}_{2}$ showed more particles upon the surface of RGO (Fig. 1E) than those upon the surface of GNPs (Fig. 1D). In addition, as determined from X-ray photoelectron spectroscopy (XPS) (Fig. S1 in SM), the GNPs and RGO surfaces consisted of $94.7 \% \mathrm{C} / 4.7 \% \mathrm{O} / 0.6 \% \mathrm{~N}$ and $94.2 \% \mathrm{C} / 5.3 \% \mathrm{O} / 0.5 \% \mathrm{~S}$, respectively. This implies that the oxygen content in the structure of RGO is slightly higher than that in the structure of GNPs.

\subsection{Algal growth inhibition toxicity}

Concentration-response curves (CRCs) were generated for all single and binary mixtures tested to which $C$. pyrenoidosa was exposed (Fig. 2). As shown in Fig. 2, a concentration-dependent increase of toxicity was observed after $72 \mathrm{~h}$ of exposure of the algae to the single compounds and the binary mixtures. Comparisons clearly show that the CRCs for the $\mathrm{nZO}_{2}$ and $\mathrm{Zr}^{4+}$-ions shifted towards lower concentrations in the presence of GNPs and RGO. As shown in Fig. 2A, the CRCs of $\mathrm{nZrO}_{2}$ in the presence of RGO deviated from the CRCs for the single $\mathrm{nZO}_{2}$ more seriously compared with the shift of the CRCs of $\mathrm{nZrO}_{2}$ in the presence of GO. Dissimilarly, the CRCs of the $\mathrm{Zr}^{4+}$-ions in the presence of GNPs/RGO of $1 \mathrm{mg} / \mathrm{L}$ deviated from the CRCs of the single $\mathrm{Zr}^{4+}$-ions more seriously (Fig. 2B) compared with the CRCs for the $\mathrm{nZOO}_{2}$ in the presence of GNPs/RGO at a concentration of $0.1 \mathrm{mg} / \mathrm{L}$. From the CRCs (Fig. 2) it is important to note that the joint action of GNPs/RGO and $\mathrm{ZZO}_{2} /$
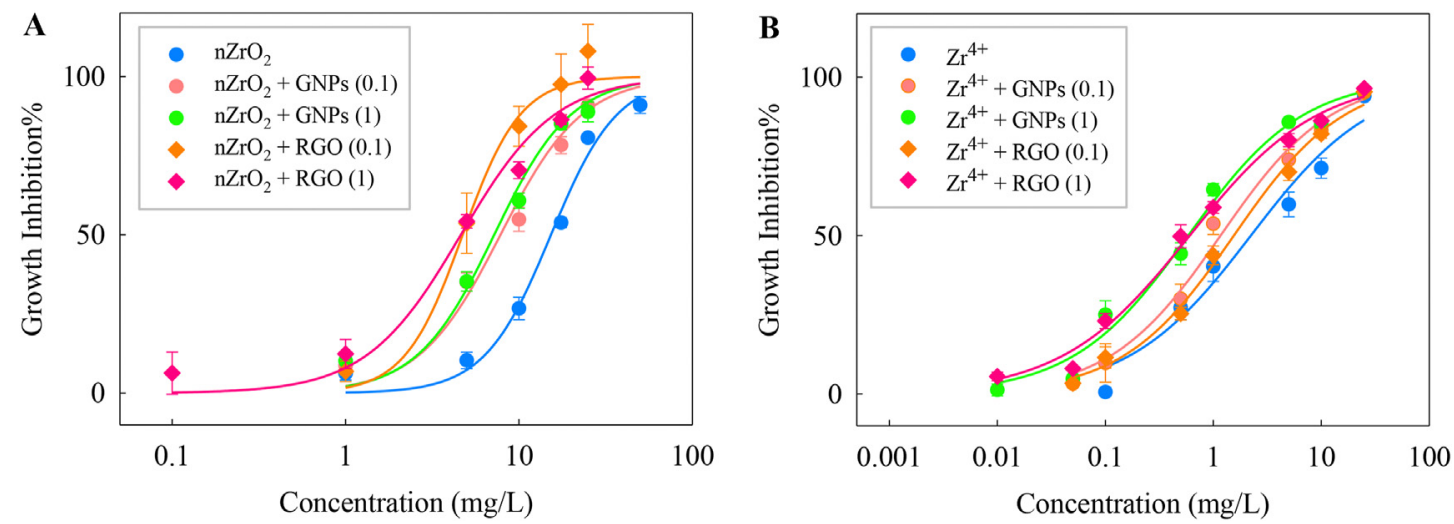

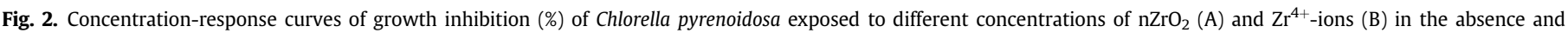
presence of two different concentrations $(0.1$ and $1 \mathrm{mg} / \mathrm{L})$ of GNPs and RGO, respectively. The values reported are expressed as mean \pm standard deviation $(n=3)$. 
Table 1

Effect concentrations for concentration-response curves of the single compounds and the binary mixtures tested ${ }^{\mathrm{a}}$.

\begin{tabular}{|c|c|c|c|c|c|}
\hline \multirow[t]{2}{*}{ Nanoparticles } & \multicolumn{2}{|c|}{$\begin{array}{l}\text { Effect concentrations } \\
(\mathrm{mg} / \mathrm{L})\end{array}$} & \multirow[t]{2}{*}{ Ions } & \multicolumn{2}{|c|}{$\begin{array}{l}\text { Effect concentrations } \\
(\mathrm{mg} / \mathrm{L})\end{array}$} \\
\hline & $E C_{50}$ & $E C_{10}$ & & $E C_{50}$ & $E C_{10}$ \\
\hline $\mathrm{nZrO}{ }_{2}$ & $\begin{array}{l}15.3 \\
{[12.0-19.6]}\end{array}$ & $\begin{array}{l}5.8 \\
{[3.1-9.3]}\end{array}$ & $\mathrm{Zr}^{4+}$ & $\begin{array}{l}2.23 \\
{[0.91-6.21]}\end{array}$ & $\begin{array}{l}0.13 \\
{[0.01-0.64]}\end{array}$ \\
\hline $\begin{array}{l}\mathrm{nZrO}_{2}+ \\
\mathrm{GNPs}(0.1)\end{array}$ & $\begin{array}{l}7.8 \\
{[2.5-17.1]}\end{array}$ & $\begin{array}{l}2.4 \\
{[0.8-7.1]}\end{array}$ & $\begin{array}{l}\mathrm{Zr}^{4+}+ \\
\mathrm{GNPs}(0.1)\end{array}$ & $\begin{array}{l}1.17 \\
{[0.80-1.96]}\end{array}$ & $\begin{array}{l}0.09 \\
{[0.03-0.21]}\end{array}$ \\
\hline $\begin{array}{l}\mathrm{nZrO}_{2}+ \\
\mathrm{GNPs}(1)\end{array}$ & $\begin{array}{l}7.2 \\
{[2.2-16.7]}\end{array}$ & $\begin{array}{l}2.3 \\
{[0.7-7.4]}\end{array}$ & $\begin{array}{l}\mathrm{Zr}^{4+}+ \\
\mathrm{GNPs}(1)\end{array}$ & $\begin{array}{l}0.59 \\
{[0.34-0.98]}\end{array}$ & $\begin{array}{l}0.04 \\
{[0.01-0.09]}\end{array}$ \\
\hline $\mathrm{nZrO}_{2}+$ & 4.7 & 2.0 & $\mathrm{Zr}^{4+}+$ & 1.55 & 0.12 \\
\hline RGO (0.1) & [1.4-12.6] & {$[0.5-6.2]$} & RGO (0.1) & {$[1.13-2.24]$} & [0.05-0.23] \\
\hline $\begin{array}{l}\mathrm{nZrO}_{2}+ \\
\mathrm{RGO}(1)\end{array}$ & $\begin{array}{l}4.6 \\
{[1.3-9.5]}\end{array}$ & $\begin{array}{l}1.2 \\
{[0.3-4.0]}\end{array}$ & $\begin{array}{l}\mathrm{Zr}^{4+}+ \\
\mathrm{RGO}(1)\end{array}$ & $\begin{array}{l}0.60 \\
{[0.43-0.86]}\end{array}$ & $\begin{array}{l}0.03 \\
{[0.01-0.06]}\end{array}$ \\
\hline
\end{tabular}

a The 95\% two-sided confidence intervals are given in brackets.

$\mathrm{Zr}^{4+}$-ions produces a greater effect than the sum of their individual effects. This implies that the GNPs/RGO and $\mathrm{nZrO}_{2} / \mathrm{Zr}^{4+}$-ions induced synergistic cytotoxicity to the algal cells.

Based on the CRCs, the observed $E C_{50}$ and $E C_{10}$ values are summarized in Table 1. No toxicity of the GNPs and RGO at the concentrations of 0.1 and $1 \mathrm{mg} / \mathrm{L}$ to $C$. pyrenoidosa was observed. The toxicity (in terms of the $E C_{50}$ and $E C_{10}$ values) of $\mathrm{nZrO}_{2}$ in the presence of GNPs and RGO was higher than the toxicity of $\mathrm{nZrO}_{2}$ when the GNPs and RGO were absent. Moreover, the toxicity (in terms of the $E C_{50}$ values) of a mixture of GNPs and RGO with $\mathrm{nZrO}_{2}$ was enhanced by a factor of approximately 2 and 3 respectively as compared to single $\mathrm{nZrO}_{2}$. This also means that the RGO had a greater impact on the toxicity increase than the GNPs. In addition, increasing the concentrations of GNPs and RGO increased the toxicity of the $\mathrm{nZrO}_{2}$. The $E C_{50}$ and $E C_{10}$ values of $\mathrm{Zr}^{4+}$-ions in the absence and presence of GNPs or RGO to $C$. pyrenoidosa were approximately 3-58 times lower than the corresponding effect values of $\mathrm{nZrO}_{2}$ in the absence and presence of GNPs or RGO (Table 1 ), showing that the $\mathrm{Zr}^{4+}$-ions are more toxic to the algae than the $\mathrm{nZrO}_{2}$ no matter whether the GNPs and RGO were present. As shown in Fig. S2, the pH value of $\mathrm{Zr}^{4+}$-ions in the absence and presence of the GNPs and RGO was significantly lower than the $\mathrm{pH}$ value of the ACM. Moreover, decreasing the $\mathrm{pH}$ value increases the toxicity. This implies that the toxicity of $\mathrm{Zr}^{4+}$-ions to the algae was associated with variation of $\mathrm{pH}$. Low $\mathrm{pH}$ might inhibit macroelement such as phosphorus uptake because the macroelements were coupled with metal ions (Lüderitz and Nicklisch, 1989). Thus, $\mathrm{pH}$ is an important factor affecting the toxicity of the $\mathrm{Zr}^{4+}$-ions to C. pyrenoidosa. Similar to the $\mathrm{nZO}_{2}$, the presence of GNPs and RGO enhanced the toxicity of $\mathrm{Zr}^{4+}$-ions. Furthermore, the higher the concentration the greater the impact. The determination of the $E C_{50}$ and $E C_{10}$ values also further confirmed the presented results of the CRCs.

The dispersion stability of NPs might play an important role in governing their toxicological effects (Peijnenburg et al., 2015; Xiao et al., 2018). To assess the agglomeration extent of $\mathrm{nZrO}_{2}$ in the presence of the GNPs and RGO, the zeta potential (Fig. S3A in SM) and the hydrodynamic diameter (Fig. S3B in SM) of the particles in suspension were measured in the single and in the binary systems. As shown in Fig. S3A in SM, the zeta potential of the particles in the single $\mathrm{nZrO}_{2}$ and binary systems were more negative than in the case of the particles in the single GNPs and RGO exposures. Zeta potential variations between -15 and $-22 \mathrm{mV}$ do have a neglectable significance on particle stability in the different suspensions. There was no difference in the zeta potential of $\mathrm{nZrO}_{2}$ in the absence and presence of GNPs or RGO. It was also found that the hydrodynamic diameter of the particles in the single $\mathrm{nZrO}_{2}$ and in the binary systems was significantly higher than in the case of the GNP and RGO alone treatments (Fig. S3B in SM). There was no difference in the hydrodynamic diameter of $\mathrm{nZrO}_{2}$ in the absence and presence of GNPs or RGO. Together, the presence of GNPs and RGO had no impact on the aggregation and dispersion stability of $\mathrm{nZrO}_{2}$. This implies that the toxicity of the binary mixtures of the $\mathrm{nZrO}_{2}$ and GNPs/RGO cannot be associated with the agglomeration and dispersion stability of the particles.

The agglomeration of NMs (especially carbon-based NMs) has been found to affect the growth of photoautotrophs in aquatic systems because of shading in previous studies (Hu et al., 2015a; Pretti et al., 2014). As shown in Fig. S3B, the hydrodynamic diameters of the GNPs and RGO were greater than those of the single $\mathrm{nZrO}_{2}$ and the binary systems, implying that the GNPs and RGO exhibited more serve agglomeration compared with the single $\mathrm{nZrO}_{2}$ and the binary systems. However, as aforementioned, no toxicity of the GNPs and RGO at the concentrations of 0.1 and $1 \mathrm{mg} /$ L was observed. It is therefore reasonable to conclude that the GNPs and RGO did not induce shading effect on the studied algae, but it had not been ruled out that the shading effect can contribute to the growth inhibition toxicity of $\mathrm{nZrO}_{2}$ in the single and binary systems to $C$. pyrenoidosa. This also means that the enhanced toxicity of $\mathrm{nZrO}_{2}$ in the presence of the GNPs and RGO was not attributed to the shading effect.

GCMs have a unique physicochemical property with unparalleled nano-topographic features, which can make use of the graphene layer to carry NPs like $\mathrm{nZrO}_{2}$ to target cells. Combined with their known-good biocompatibility, the GNPs and RGO can further promote cellular uptake and bioavailability of $\mathrm{nZO}_{2}$ or $\mathrm{Zr}^{4+}$. This might cause the enhancement of the toxicity of $\mathrm{nZO}_{2}$ and $\mathrm{Zr}^{4+}$ to the algae when the GNPs or RGO were present. Further, the expanded and corrugated nanosheets of RGO (Fig. 1C) are better for carrying the $\mathrm{nZrO}_{2}$ than the GNPs with smooth and tight nanosheets (Fig. 1B), which possibly made RGO had a more significant impact on the toxicity of $\mathrm{nZrO}_{2}$ than the GNPs. Moreover, the surface oxygen groups of RGO provides more reaction sites for adsorption with the particles or interaction with the algal cells than GNPs, as indicated by the XPS analysis results.

\subsection{Cellular oxidative stress modulation}

Due to the fact that ROS can attack cellular components such as proteins, lipids, and nucleic acids, ROS are important for cell signaling under normal physiological conditions (Applerot et al., 2012). Hence, the level of intracellular ROS has been seen as a common indicator to evaluate the cytotoxicity of ENPs (Hu et al., 2015b; Setyawati et al., 2015). As shown in Fig. 3A, the individual GNPs, RGO, and $\mathrm{Zr}^{4+}$-ions in the absence and presence of GNPs and RGO did not significantly change the ROS level in the algal cells. However, compared to the control, the $\mathrm{nZrO}_{2}$ alone and the binary mixtures of $\mathrm{nZrO}_{2}$ and GNPs/RGO induced a higher level of ROS generation. Moreover, $\mathrm{nZrO}_{2}$ induced a higher level of ROS generation in the algal cells in a dose-dependent manner. Furthermore, the binary mixtures of $\mathrm{nZO}_{2}$ and $\mathrm{RGO}$ exhibited a distinct response with a significant increase in ROS generation compared to the $\mathrm{nZrO}_{2}$ and RGO alone. This result implies that $\mathrm{nZrO}_{2}$ and $\mathrm{RGO}$ synergistically caused oxidative stress in the algal cells. A comparison of the average of the ROS levels generated hinted that increasing the concentration of the GNPs or RGO increased the amount of ROS produced by the binary mixtures within the cells. All these findings were consistent with the results of the growth inhibition toxicity testing.

To better understand the findings of the intracellular oxidative stress biomarker assays, we tracked the ROS accumulated in the algal cells, as shown in Fig. 3B-J and Fig. S4 in SM. The extent of 

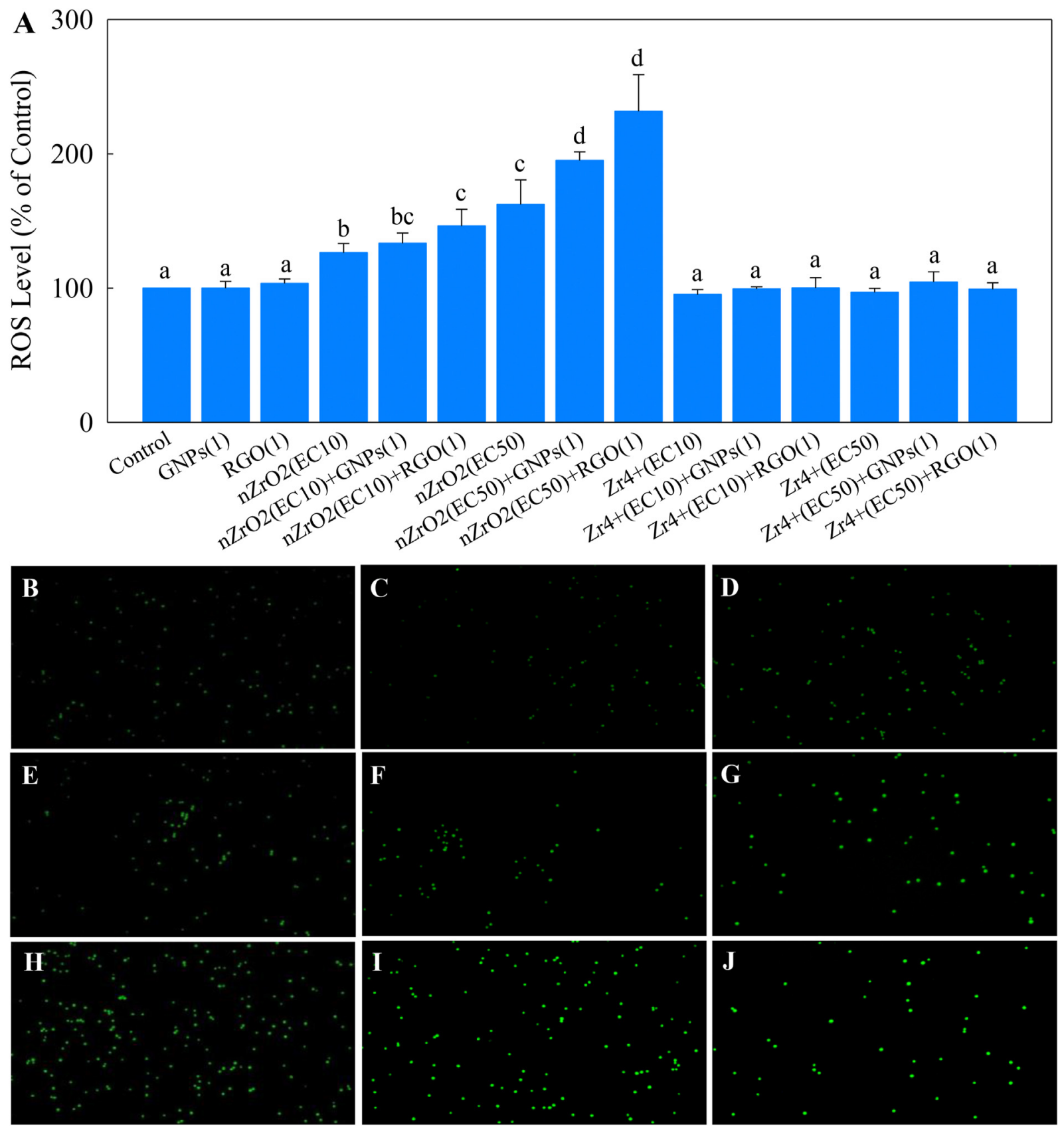

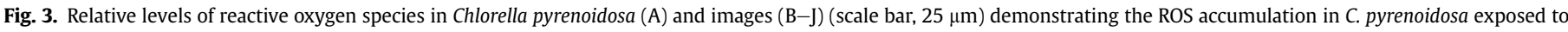

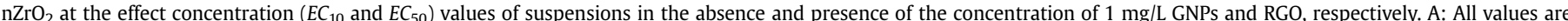

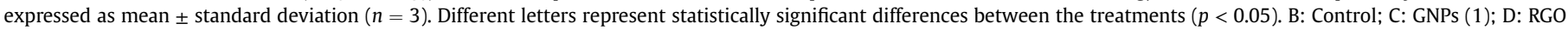
(1); E: $\mathrm{nZrO}_{2}\left(E C_{10}\right) ; \mathrm{F}: \mathrm{nZrO}_{2}\left(E C_{10}\right)+\mathrm{GNPs}(1) ; \mathrm{G}: \mathrm{nZrO}_{2}\left(E C_{10}\right)+\mathrm{RGO}(1) ; \mathrm{H}: \mathrm{nZrO}_{2}\left(E C_{50}\right) ; \mathrm{I}: \mathrm{nZrO}_{2}\left(E C_{50}\right)+\mathrm{GNPs}(1) ; \mathrm{J}: \mathrm{nZrO} \mathrm{r}_{2}\left(E C_{50}\right)+\mathrm{RGO}(1)$.

intracellular ROS accumulation reflected the oxidative damage of the algae cells exposed to the different treatments. Generally, the cells treated by $\mathrm{nZrO}_{2}$ singly and by the binary mixtures of $\mathrm{nZrO}_{2}$ and GNPs/RGO (Fig. 3E-J) showed a stronger vivid green fluorescence than any of the other treatments. This indicates that $\mathrm{nZrO}_{2}$ induced intracellular ROS accumulation in the algae.

Compared with single $\mathrm{nZrO}_{2}$, the presence of GNPs and RGO increased the accumulation of intracellular ROS. Especially, the binary mixtures of $\mathrm{nZrO}_{2}$ at the $E C_{50}$ value and the GNPs/RGO at $1 \mathrm{mg} / \mathrm{L}$ gave rise to high intracellular production of ROS in the algae cells (Fig. 3I and J), implying that the binary mixtures might invoke more serious oxidative intracellular stress. These findings showcased the synergistic effect triggered by the $\mathrm{nZrO}_{2}$ and GNPs/ RGO on the level of ROS accumulated in the algal cells. On the other hand, the intracellular ROS accumulation induced by the $\mathrm{Zr}^{4+}$-ion treatments was not significantly different from the ROS levels present in the control group (Fig. S4 in SM). This also means that the effect of GNPs and RGO on the cytotoxicity mechanism of $\mathrm{nZrO}_{2}$ completely differed from the impacts of GNPs and RGO on the mechanism of cytotoxicity of $\mathrm{Zr}^{4+}$-ions.

\subsection{Cellular membrane function disturbance}

The stability of cellular membrane permeability (CMP) and 
mitochondrial membrane potential (MMP) is beneficial to maintain the normal physiological function of cells (dos Santos et al., 2012). As shown in Fig. S5A in SM, the $\mathrm{nZrO}_{2}$ alone significantly increased the CMP in the algal cells in comparison with the control. Moreover, increasing the concentration of $\mathrm{nZrO}_{2}$ increased the CMP in the algal cells. In addition, the CMP of the algae cells treated by the binary mixtures of $\mathrm{nZrO}_{2}$ and GNPs/RGO showed a clear increase, of which the most significant increase was in the binary mixtures of $\mathrm{nZrO}_{2}$ and RGO. In addition, the single GNPs, RGO, $\mathrm{Zr}^{4+}$-ions, and their combined systems had no impacts on the CMP. As shown in Fig. S5B in SM, the MMP of the algae cells treated by the $\mathrm{nZrO}_{2}$ alone and the binary mixtures of $\mathrm{nZOO}_{2}$ and GNPs/RGO at $1 \mathrm{mg} / \mathrm{L}$ also showed a clear increase. The accumulation of intracellular ROS may lead to an increase in MMP, resulting in the functioning of mitochondria to be affected (Amado and Monserrat, 2010). This result suggested that mitochondria contributed mainly to the accumulation of ROS in the algae cells. Collectively, these findings also indicate that GNPs/RGO and $\mathrm{nZrO}_{2}$ synergistically disturbed the cellular membrane function.

\subsection{Cellular structural damage}

To further examine the findings from the biomarker assays, we observed the superficial- and ultra-structures of $C$. pyrenoidosa cells exposed to the single and binary mixtures of $\mathrm{nZrO}_{2}$ and GNPs/RGO by means of SEM (Fig. 4) and TEM (Fig. 5), respectively. Accumulated $\mathrm{nZrO}_{2}$ on the cellular surface can clearly be discerned in the images, as presented in Fig. 4G-J. Compared with the control (Fig. 4A and B), the cells exposed to the binary mixtures showed serious cell-cell adhesion (Fig. $4 \mathrm{~J}$ and $\mathrm{L}$ ). It is noteworthy that a structural defect in the cell surface was observed in a single cell when the $\mathrm{nZrO}_{2}$ and GNPs/RGO coexisted (Fig. $4 \mathrm{I}$ and $\mathrm{K}$ ). The ultrastructures of the algae were determined to elucidate whether the particles can enter the algal cells and the effect of the particles on the algal cell ultra-structures. The $C$. pyrenoidosa cells in control contained a well-organized structure of organelle (Fig. 5A), while many ultra-structure details of the algal cells after the particle exposure could not be recognized (Fig. 5B-D), implying their toxicity inside the cell structures. Particle-mediated ROS accumulation and subsequent oxidative stress responses were the likely mechanisms for the cellular structure damage. This further supports our hypothesis that the ROS generated by the binary mixtures triggered the oxidative stress on the exposed algae. Rather, compared with the control, no obvious structural change was observed for the individual GNPs and RGO (Fig. 4C-F). Therefore, the results reported here further provide direct evidence of $\mathrm{nZO}_{2}$ and GNPs/RGO synergistically inducing oxidative damage to the algal cells.

\section{Conclusions}

In summary, we provided evidence that GNPs and RGO elevated the cytotoxicity of $\mathrm{nZrO}_{2}$ to $C$. pyrenoidosa. As the results show, the mechanism underlying the joint toxic action was associated with the induction of intracellular oxidative stress and cellular membrane functional changes by the NPs/NP mixtures. Moreover, the intracellular oxidative stress is activated via a mitochondriagenerated ROS-dependent mechanism. Observations of cellular superficial- and ultra-structures indicated that the elevated ROS levels induced significant oxidative damage to the algal cellular structure, resulting in subsequent cell growth inhibition. A comparison of the impacts of GNPs and RGO showed that RGO induced more cytotoxic responses from the cells, including intracellular ROS accumulation, cellular membrane disruption, and cell growth inhibition. Given that our nanotechnological-based innovations nowadays contain a multitude of different nanomaterials, co-
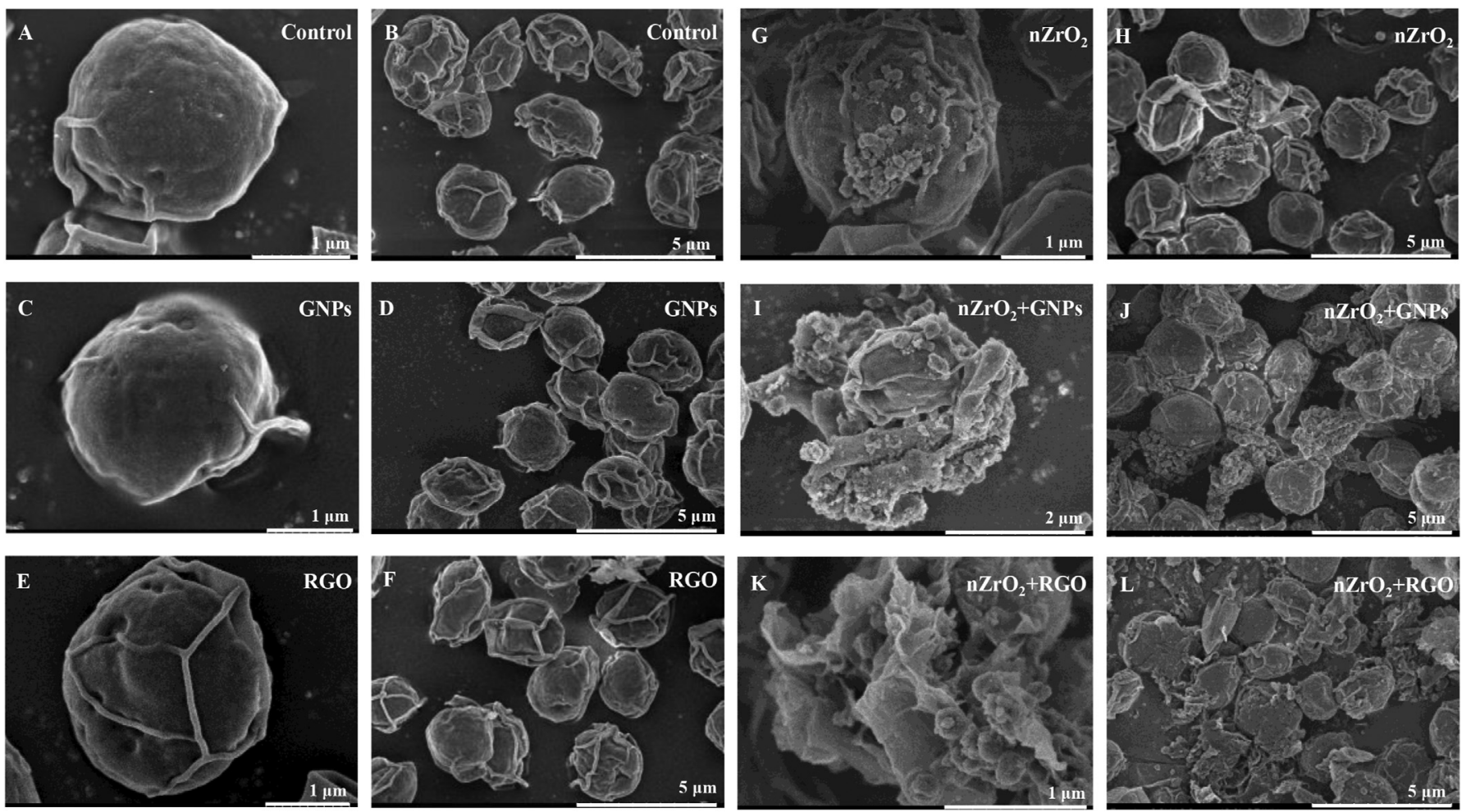

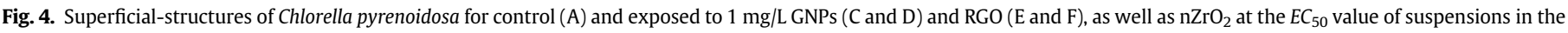
absence ( $\mathrm{G}$ and $\mathrm{H}$ ) and presence of the concentration of $1 \mathrm{mg} / \mathrm{L} \mathrm{GNPs}$ (I and J) and RGO (K and $\mathrm{L}$ ), respectively. 

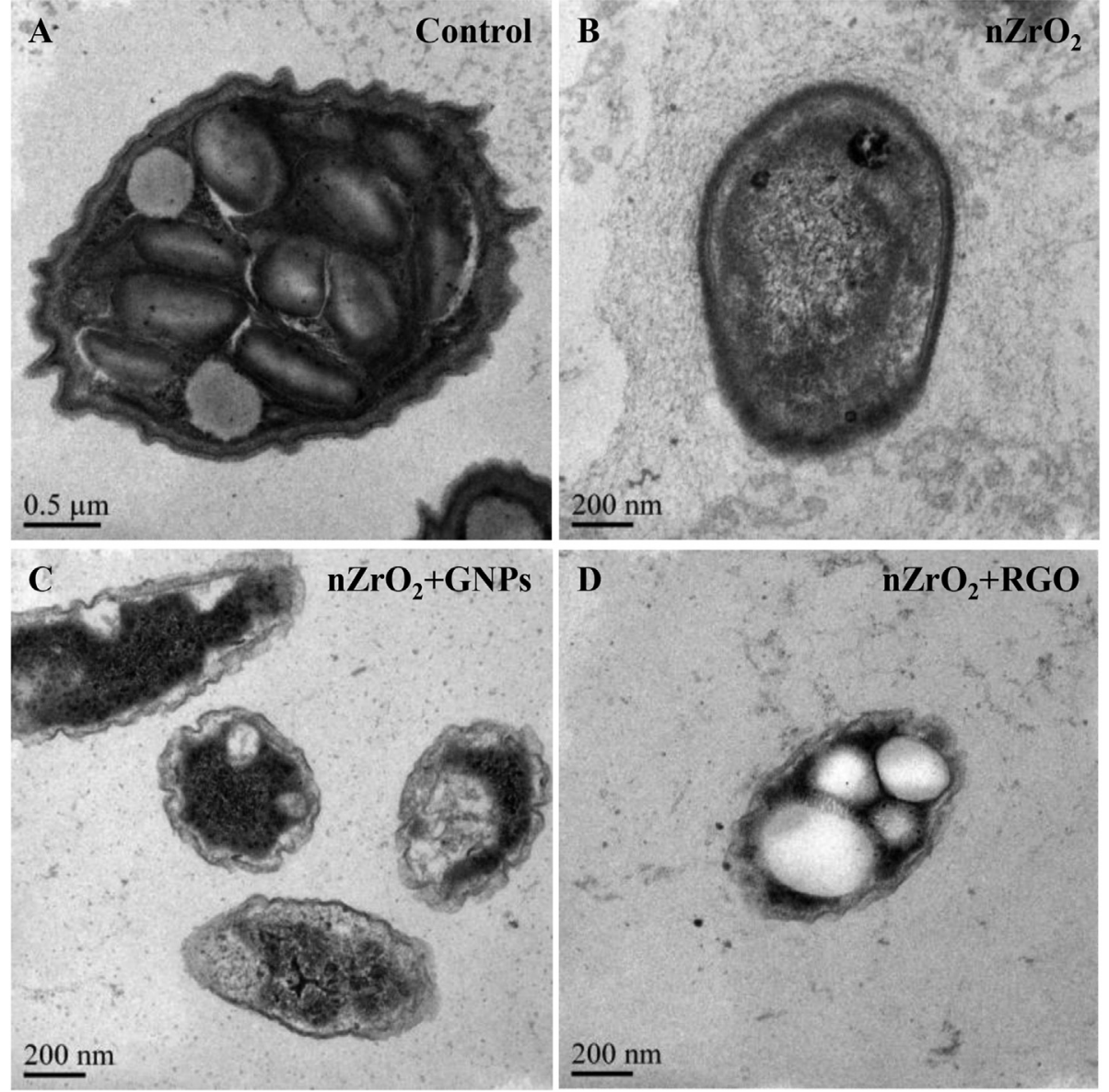

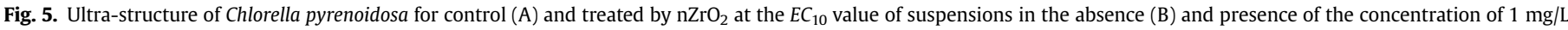
GNPs (C) and RGO (D), respectively.

exposures are likely to occur in the environment. Joint impacts of binary NMs as addressed in this study are the first stepping stone to address these new safety questions on graphene-based materials with for instance $\mathrm{nZrO}_{2}$ that will more widely find its applications in products.

\section{Supplementary material}

XPS survey spectra of GNPs and RGO; pH values of the test medium, $50 \mathrm{mg} / \mathrm{L} \mathrm{nZrO}$ and $25 \mathrm{mg} / \mathrm{L} \mathrm{Zr}^{4+}$-ions in the absence and presence of $1 \mathrm{mg} / \mathrm{L}$ GNPs and RGO. The studied concentration represent the highest exposure concentration for each treatment in the toxicity testing; Zeta potential and hydrodynamic diameter of the individual and binary mixtures of $\mathrm{nZrO}_{2}$ at the effect concentration $\left(E C_{50}\right.$ and $\left.E C_{10}\right)$ values of suspensions in the absence and presence of GNPs and RGO of $1 \mathrm{mg} / \mathrm{L}$, respectively; Images (scale bar, $25 \mu \mathrm{m}$ ) demonstrating the ROS accumulation in $C$. pyrenoidosa exposed to $\mathrm{Zr}^{4+}$-ions at the effect concentration $\left(E C_{10}\right.$ and $\left.E C_{50}\right)$ values of suspensions in the absence and presence of the concentration of $1 \mathrm{mg} / \mathrm{L}$ GNPs and RGO, respectively; and cellular membrane permeability and mitochondrial membrane potential of the algae exposed to the various treatments.

\section{Credit author contribution statement}

Zhuang Wang: Conceptualization, Methodology, Resources, Investigation, Data curation, Formal analysis, Writing - original draft preparation, Visualization, Funding acquisition, Project administration. Fan Zhang: Conceptualization, Visualization, Writing - review \& editing. Martina G. Vijver: Conceptualization, Writing - review \& editing, Funding acquisition, Project administration. Willie J. G. M. Peijnenburg: Conceptualization, Writing review \& editing, Funding acquisition, Project administration.

\section{Declaration of competing interest}

The authors declare that they have no known competing financial interests or personal relationships that could have appeared to influence the work reported in this paper.

\section{Acknowledgments}

The research described in this work was supported by the National Natural Science Foundation of China (31971522) and the Natural Science Foundation of Jiangsu Province (BK20191403). This work was also supported by the European Union's Horizon 2020 research and innovation program "NanoinformaTIX" (814426). We also thank the reviewers for their valuable comments on the manuscript.

\section{Appendix A. Supplementary data}

Supplementary data to this article can be found online at https://doi.org/10.1016/j.chemosphere.2021.130015. 


\section{References}

Amado, L.L., Monserrat, J.M., 2010. Oxidative stress generation by microcystins in aquatic animals: why and how. Environ. Int. 36, 226-235.

Applerot, G., Lellouche, J., Lipovsky, A., Nitzan, Y., Lubart, R., Gedanken, A., Banin, E., 2012. Understanding the antibacterial mechanism of CuO nanoparticles: revealing the route of induced oxidative stress. Small 8 (21), 3326-3337.

Bangeppagari, M., Park, S.H., Kundapur, R.R., Lee, S.J., 2019. Graphene oxide induces cardiovascular defects in developing zebrafish (Danio rerio) embryo model: invivo toxicity assessment. Sci. Total Environ. 673, 810-820.

Brar, S.K., Verma, M., Tyagi, R.D., Surampalli, R.Y., 2010. Engineered nanoparticles in wastewater and wastewater sludge-evidence and impacts. Waste Manag. 30 (3), 504-520.

Cano, A.M., Maul, J.D., Saed, M., Shah, S.A., Green, M.J., Cañas-Carrell, J.E., 2017. Bioaccumulation, stress, and swimming impairment in Daphnia magna exposed to multiwalled carbon nanotubes, graphene, and graphene oxide. Environ. Toxicol. Chem. 36 (8), 2199-2204.

Castro, V.L., Clemente, Z., Jonsson, C., Silva, M., Vallim, J.H., Medeiros, A.M.Z. de, Martinez, D.S.T., 2018. Nanoecotoxicity assessment of graphene oxide and its relationship with humic acid. Environ. Toxicol. Chem. 37 (7), 1998-2012.

Chen, L., Li, J., Chen, Z., Gu, Z., Yan, L., Zhao, F., Zhang, A., 2020. Toxicological evaluation of graphene-family nanomaterials. J. Nanosci. Nanotechnol. 20 (4), 1993-2006.

Chen, P., Powell, B.A., Mortimer, M., Ke, P.C., 2012. Adaptive interactions between zinc oxide nanoparticles and Chlorella sp. Environ. Sci. Technol. 46 (21), $12178-12185$

Cho, B.H., Ko, W.B., 2013. Preparation of graphene- $\mathrm{ZrO}_{2}$ nanocomposites by heat treatment and photocatalytic degradation of organic dyes. J. Nanosci. Nanotechnol. 13 (11), 7625-7630.

dos Santos, G.A.S., Abreu e Lima, R.S., Pestana, C.R., Lima, A.S.G., Scheucher, P.S., Thomé, C.H., Gimenes-Teixeira, H.L., Santana-Lemos, B.A.A., Lucena-Araujo, A.R., Rodrigues, F.P. Nasr, R. Uyemura, S.A., Falcão, R.P., Thé, H. de, Pandolfi, P.P., Curti, C., Rego, E.M., 2012. (+) $\alpha$-Tocopheryl succinate inhibits the mitochondrial respiratory chain complex $\mathrm{I}$ and is as effective as arsenic trioxide or ATRA against acute promyelocytic leukemia in vivo. Leukemia 26 (3), 451-460.

Du, S., Zhang, P., Zhang, R., Lu, Q., Liu, L., Bao, X., Liu, H., 2016. Reduced graphene oxide induces cytotoxicity and inhibits photosynthetic performance of the green alga Scenedesmus obliquus. Chemosphere 164, 499-507.

Fadeel, B., Bussy, C., Merino, S., Vázquez, E., Flahaut, E., Mouchet, F., Evariste, L., Gauthier, L., Koivisto, A.J., Vogel, U., Martín, C., Delogu, L.G., Buerki-Thurnherr, T., Wick, P., Beloin-Saint-Pierre, D., Hischier, R., Pelin, M., Candotto Carniel, F., Tretiach, M., Cesca, F., Benfenati, F., Scaini, D., Ballerini, L., Kostarelos, K., Prato, M., Bianco, A., 2018. Safety assessment of graphene-based materials: focus on human health and the environment. ACS Nano 12 (11), 10582-10620.

Feng, Y., Lu, K., Mao, L., Guo, X., Gao, S., Petersen, E.J., 2015. Degradation of (14)Clabeled few layer graphene via Fenton reaction: reaction rates, characterization of reaction products, and potential ecological effects. Water Res. 84, 49-57.

Freixa, A., Acuña, V., Sanchís, J., Farré, M., Barceló, D., Sabater, S., 2018. Ecotoxicological effects of carbon based nanomaterials in aquatic organisms. Sci. Total Environ. 619-620, 328-337.

Hu, C., Wang, Q., Zhao, H., Wang, L., Guo, S., Li, X., 2015a. Ecotoxicological effects of graphene oxide on the protozoan Euglena gracilis. Chemosphere 128, 184-190.

Hu, X, Ouyang S., Mu, Li, An, J., Zhou, O, 2015b. Effects of graphene oxide and oxidized carbon nanotubes on the cellular division, microstructure, uptake, oxidative stress, and metabolic profiles. Environ. Sci. Technol. 49 (18), 10825-10833.

Hua, J., Peijnenburg, W.J., Vijver, M.G., 2016. $\mathrm{TiO}_{2}$ nanoparticles reduce the effects of $\mathrm{ZnO}$ nanoparticles and $\mathrm{Zn}$ ions on zebrafish embryos (Danio rerio). NanoImpact 2, 45-53.

Jafari, M.T., Rezaei, B., Bahrami, H., 2018. Zirconium dioxide-reduced graphene oxide nanocomposite-coated stir-bar sorptive extraction coupled with ion mobility spectrometry for determining ethion. Talanta 182, 285-291.

Koivisto, A.J., Jensen, A.C.Ø., Kling, K.I., Nørgaard, A., Brinch, A., Christensen, F., Jensen, K.A., 2017. Quantitative material releases from products and articles containing manufactured nanomaterials: towards a release library. NanoImpact 5, 119-132.

Liu, C., Hajagos, T.J., Chen, D., Chen, Y., Kishpaugh, D., Pei, Q., 2016. Efficient one-pot synthesis of colloidal zirconium oxide nanoparticles for high-refractive-index nanocomposites. ACS Appl. Mater. Interfaces 8, 4795-4802.

Liu, Y., Wang, S., Wang, Z., Ye, N., Fang, H., Wang, D., 2018. TiO $2, \mathrm{SiO}_{2}$ and $\mathrm{ZrO}_{2}$ nanoparticles synergistically provoke cellular oxidative damage in freshwater microalgae. Nanomaterials 8, 95.

Lüderitz, V., Nicklisch, A., 1989. The effect of pH on copper toxicity to blue-green algae. Hydrobiol. (Sofia) 74, 283-291.

Lv, X., Yang, Y., Tao, Y., Jiang, Y., Chen, B., Zhu, X., Cai, Z., Li, B., 2018. A mechanism study on toxicity of graphene oxide to Daphnia magna: direct link between bioaccumulation and oxidative stress. Environ. Pollut. 234, 953-959.

Ma, C., White, J.C., Dhankher, O.P., Xing, B., 2015. Metal-based nanotoxicity and detoxification pathways in higher plants. Environ. Sci. Technol. 49 (12),
$7109-7122$

Manjunatha, B., Park, S.H., Kim, K., Kundapur, R.R., Lee, S.J., 2018. Pristine graphene induces cardiovascular defects in zebrafish (Danio rerio) embryogenesis. Environ. Pollut. 243 (Pt A), 246-254.

Marchi, L. de, Pretti, C., Gabriel, B., Marques, P.A.A.P., Freitas, R., Neto, V., 2018. An overview of graphene materials: properties, applications and toxicity on aquatic environments. Sci. Total Environ. 631-632, 1440-1456.

Meng, Y., Wang, S., Wang, Z., Ye, N., Fang, H., 2018. Algal toxicity of binary mixtures of zinc oxide nanoparticles and tetrabromobisphenol A: roles of dissolved organic matters. Environ. Toxicol. Pharmacol. 64, 78-85.

Nogueira, P.F.M., Nakabayashi, D., Zucolotto, V., 2015. The effects of graphene oxide on green algae Raphidocelis subcapitata. Aquat. Toxicol. 166, 29-35.

OECD, 2006. Guidelines for Testing of Chemicals. Freshwater Alga and Cyanobacteria, Growth Inhibition Test No. 201.

Peijnenburg, W.J.G.M., Baalousha, M., Chen, J., Chaudry, Q., kammer, F. von der, Kuhlbusch, T.A.J., Lead, J., Nickel, C., Quik, J.T.K., Renker, M., Wang, Z. Koelmans, A.A., 2015. A review of the properties and processes determining the fate of engineered nanomaterials in the aquatic environment. Crit. Rev. Environ. Sci. Technol. 45 (19), 2084-2134.

Peng, Z., Liu, X., Zhang, W., Zeng, Z., Liu, Z., Zhang, C., Liu, Y., Shao, B., Liang, Q., Tang, W., Yuan, X., 2020. Advances in the application, toxicity and degradation of carbon nanomaterials in environment: a review. Environ. Int. 134, 105298.

Pretti, C., Oliva, M., Di Pietro, R., Monni, G., Cevasco, G., Chiellini, F., Pomelli, C., Chiappe, C., 2014. Ecotoxicity of pristine graphene to marine organisms. Ecotoxicol. Environ. Saf. 101, 138-145.

Setyawati, M.I., Tay, C.Y., Leong, D.T., 2015. Mechanistic investigation of the biological effects of $\mathrm{SiO}_{2}, \mathrm{TiO}_{2}$, and $\mathrm{ZnO}$ nanoparticles on intestinal cells. Small 11 (28), 3458-3468.

Sohn, E.K., Chung, Y.S., Johari, S.A., Kim, T.G., Kim, J.K., Lee, J.H., Lee, Y.H., Kang, S.W., Yu, I.J., 2015. Acute toxicity comparison of single-walled carbon nanotubes in various freshwater organisms. BioMed Res. Int. 2015, 323090.

Sousa, V.S., Ribau Teixeira, M., 2020. Metal-based engineered nanoparticles in the drinking water treatment systems: a critical review. Sci. Total Environ. 707, 136077.

Srivastava, V., Gusain, D., Sharma, Y.C., 2015. Critical review on the toxicity of some widely used engineered nanoparticles. Ind. Eng. Chem. Res. 54 (24), 6209-6233.

Suárez-Iglesias, O., Collado, S., Oulego, P., Díaz, M., 2017. Graphene-family nanomaterials in wastewater treatment plants. Chem. Eng. J. 313, 121-135.

Sun, C., Li, W., Xu, Y., Hu, N., Ma, J., Cao, W., Sun, S., Hu, C., Zhao, Y., Huang, Q., 2020. Effects of carbon nanotubes on the toxicities of copper, cadmium and zinc toward the freshwater microalgae Scenedesmus obliquus. Aquat. Toxicol. 224, 105504.

Sun, W., Wang, X., Sun, X., Deng, Y., Liu, J., Lei, B., Sun, Z., 2013. Simultaneous electrochemical determination of guanosine and adenosine with graphene$\mathrm{ZrO}_{2}$ nanocomposite modified carbon ionic liquid electrode. Biosens. Bioelectron. 44, 146-151.

Tsugita, M., Morimoto, N., Nakayama, M., 2017. $\mathrm{SiO}_{2}$ and $\mathrm{TiO}_{2}$ nanoparticles synergistically trigger macrophage inflammatory responses. Part. Fibre Toxicol 14 (1), 11.

Wang, Q., Li, C., Wang, Y., Que, X., 2019. Phytotoxicity of graphene family nanomaterials and its mechanisms: a review. Front. Chem. 7, 292.

Wu, B., Wu, J., Liu, S., Shen, Z., Chen, L., Zhang, X.-X., Ren, H., 2019. Combined effects of graphene oxide and zinc oxide nanoparticle on human A549 cells: bioavailability, toxicity and mechanisms. Environ. Sci.: Nano 6 (2), 635-645.

Xiao, Y., Peijnenburg, W.J.G.M., Chen, G., Vijver, M.G., 2018. Impact of water chemistry on the particle-specific toxicity of copper nanoparticles to Daphnia magna. Sci. Total Environ. 610-611, 1329-1335.

Ye, N., Wang, Z., Wang, S., Peijnenburg, W.J.G.M., 2018. Toxicity of mixtures of zinc oxide and graphene oxide nanoparticles to aquatic organisms of different trophic level: particles outperform dissolved ions. Nanotoxicology 12 (5), 423-438.

Yin, Z., Cui, C., Chen, H., Duoni Yu, X., Qian, W., 2020. The application of carbon nanotube/graphene-based nanomaterials in wastewater treatment. Small 16 (15), e1902301.

Yu, R., Wu, J., Liu, M., Zhu, G., Chen, L., Chang, Y., Lu, H., 2016. Toxicity of binary mixtures of metal oxide nanoparticles to Nitrosomonas europaea. Chemosphere 153, 187-197.

Zhao, J., Cao, X., Wang, Z., Dai, Y., Xing, B., 2017. Mechanistic understanding toward the toxicity of graphene-family materials to freshwater algae. Water Res. 111, $18-27$.

Zhao, Y., Sugiyama, S., Miller, T., Miao, X., 2008. Nanoceramics for blood-borne virus removal. Expet Rev. Med. Dev. 5, 395-405.

Zheng, M., Lu, J., Lin, G., Su, H., Sun, J., Luan, T., 2019. Dysbiosis of gut microbiota by dietary exposure of three graphene-family materials in zebrafish (Danio rerio). Environ. Pollut. 254 (Pt A), 112969.

Zhou, H., Shen, Y., Xi, J., Qiu, X., Chen, L., 2016. ZrOn-nanoparticle-modified graphite felt: bifunctional effects on vanadium flow batteries. ACS Appl. Mater. Interfaces 8 (24), 15369-15378. 